\title{
Sphingomonas hankookensis sp. nov., isolated from wastewater
}

Correspondence
Jung-Hoon Yoon
jhyoon@kribb.re.kr

The genus Sphingomonas, first described by Yabuuchi et al. (1990), belongs phylogenetically to the Alphaproteobacteria (Anzai et al., 2000; Lee et al., 2005). At the time of writing, the genus comprises at least 39 recognized species, including the recently described species Sphingomonas insulae (Yoon et al., 2008), Sphingomonas sanxanigenens (Huang et al., 2009) and Sphingomonas japonica (Romanenko et al., 2009). In the present study, we report the taxonomic characterization of a Sphingomonas-like bacterial strain, $\mathrm{ODN}^{\mathrm{T}}$, which was isolated from a wastewater treatment plant in Korea.

Strain $\mathrm{ODN}^{\mathrm{T}}$ was isolated by means of the standard dilution plating technique on $10 \times$ diluted nutrient agar (Difco) at $30^{\circ} \mathrm{C}$. The type strains of five recognized Sphingomonas species were used as reference strains for DNA-DNA hybridization and phenotypic characterizations: Sphingomonas panni KACC $12169^{\mathrm{T}}$ and Sphingomonas desiccabilis KACC $13216^{\mathrm{T}}$ were obtained from the Korean Agricultural Culture Collection, Suwon, Korea; Sphingomonas mucosissima DSM $17494^{\mathrm{T}}$ was

The GenBank/EMBL/DDBJ accession number for the 16S rRNA gene sequence of strain ODN7 ${ }^{\top}$ is FJ194436. obtained from the Deutsche Sammlung von Mikroorganismen und Zellkulturen (DSMZ), Braunschweig, Germany; Sphingomonas molluscorum JCM $14122^{\mathrm{T}}$ was obtained from the Japan Collection of Microorganisms (JCM), Saitama, Japan, and Sphingomonas dokdonensis DS- $4^{\mathrm{T}}$ was obtained from the study of Yoon et al. (2006). The morphological, physiological and biochemical characteristics of strain $\mathrm{ODN}^{\mathrm{T}}$ were investigated by using routine cultivation on trypticase soy agar (TSA; Difco) at $30{ }^{\circ} \mathrm{C}$. Cell morphology was examined by light microscopy (E600; Nikon) by using cells from exponentially growing cultures. The Gram reaction was determined by using the bioMérieux Gram stain kit according to the manufacturer's instructions. Growth at various temperatures $(4,15,20,25$, $28,30,35,37,40$ and $45^{\circ} \mathrm{C}$ ) was measured on TSA. The $\mathrm{pH}$ range for growth was determined in nutrient broth (Difco) adjusted, prior to sterilization, to various $\mathrm{pH}$ values (4.5-10.5 at intervals of $0.5 \mathrm{pH}$ units) by the addition of $\mathrm{HCl}$ or $\mathrm{Na}_{2} \mathrm{CO}_{3}$. Growth at various $\mathrm{NaCl}$ concentrations $(0-5.0 \%, \mathrm{w} / \mathrm{v}$, at increments of $1.0 \%)$ was investigated by using trypticase soy broth prepared according to the formula of the Difco medium except that $\mathrm{NaCl}$ was excluded from the medium formula. Growth under 
anaerobic conditions was determined after incubation in an anaerobic chamber on TSA and on TSA supplemented with potassium nitrate $(0.1 \%$, w/v), both of which had been prepared anaerobically under a nitrogen atmosphere. Catalase and oxidase activities and hydrolysis of casein, gelatin, hypoxanthine, starch, Tweens 20, 40, 60 and 80, tyrosine, urea and xanthine were determined as described by Cowan \& Steel (1965). Hydrolysis of aesculin and reduction of nitrate were studied as described by Lányí (1987). Susceptibility to antibiotics was tested on TSA plates by using antibiotic discs containing the following compounds: polymyxin B (100 U), streptomycin $(50 \mu \mathrm{g})$, penicillin $\mathrm{G}(20 \mathrm{U})$, chloramphenicol $(100 \mu \mathrm{g})$, ampicillin $(10 \mu \mathrm{g})$, cephalothin $(30 \mu \mathrm{g})$, gentamicin $(30 \mu \mathrm{g})$, novobiocin $(5 \mu \mathrm{g})$, tetracycline $(30 \mu \mathrm{g})$, kanamycin $(30 \mu \mathrm{g})$, lincomycin $(15 \mu \mathrm{g})$, oleandomycin $(15 \mu \mathrm{g})$, neomycin $(30 \mu \mathrm{g})$ and carbenicillin $(100 \mu \mathrm{g})$. Utilization of various substrates, enzyme activities and other physiological and biochemical properties were tested by using the API 20E, API 20NE and API 50CH systems (bioMérieux). Cells were suspended in AUX medium according to the manufacturer's instructions to inoculate the API $50 \mathrm{CH}$ system.

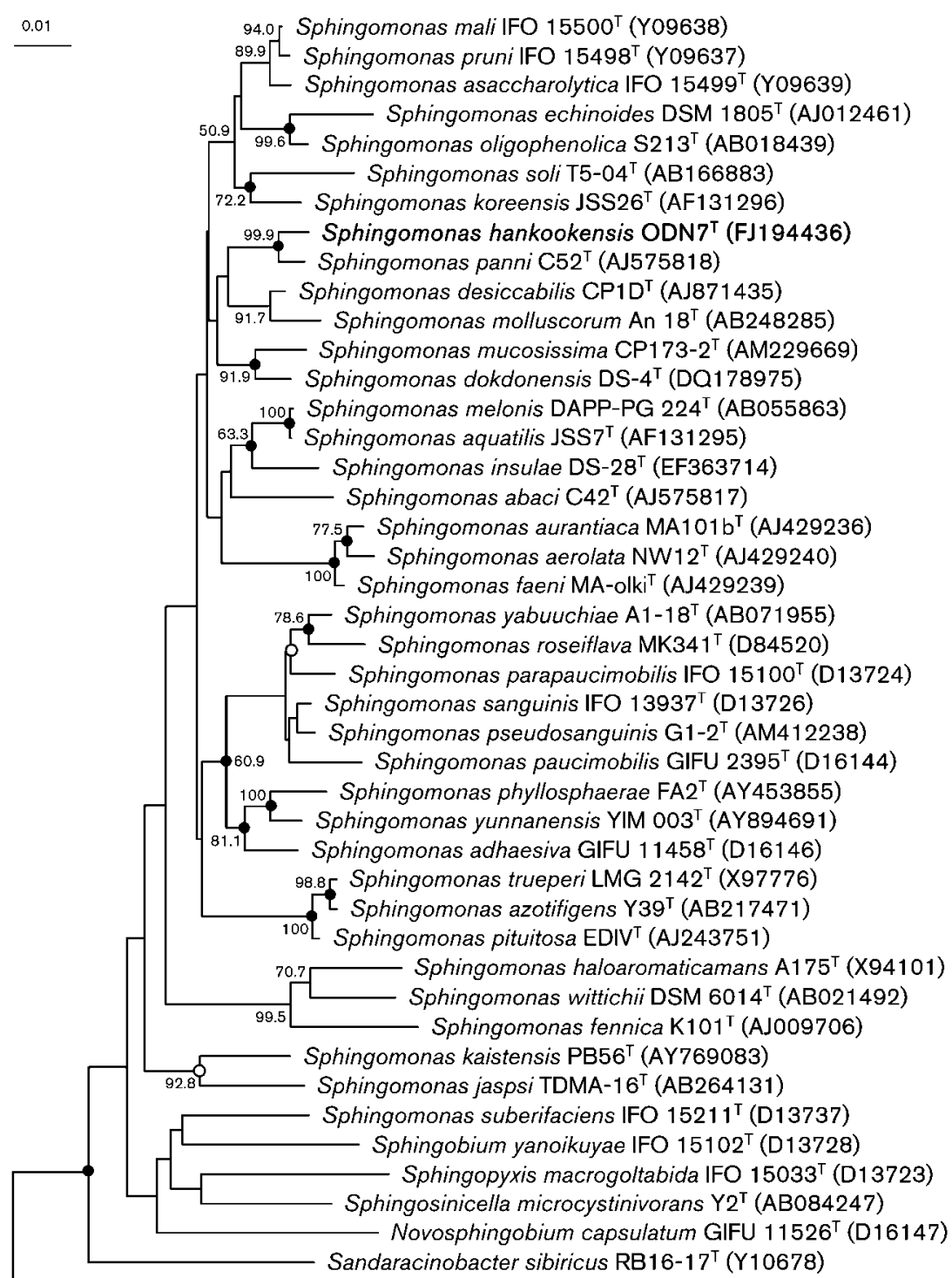

Rhodospirillum rubrum ATCC $11170^{\top}$ (D30778)

Fig. 1. Neighbour-joining phylogenetic tree based on $16 \mathrm{~S}$ rRNA gene sequences showing the position of strain ODN7 ${ }^{\top}$ among other related taxa. Filled circles indicate that the corresponding nodes were also recovered in the trees generated with the maximum-likelihood and maximum-parsimony algorithms. Open circles indicate that the corresponding nodes were also recovered in the tree generated with the maximum-likelihood algorithm. Rhodospirillum rubrum ATCC $11170^{\top}$ was used as an outgroup. Bar, 0.01 substitutions per nucleotide position. 
Cell biomass for DNA extraction and for analysis of isoprenoid quinones and polar lipids was obtained from cultivation in trypticase soy broth (Difco) at $30{ }^{\circ} \mathrm{C}$. Chromosomal DNA was isolated and purified according to the method described by Yoon et al. (1996), with the exception that RNase T1 was used in combination with RNase A to minimize contamination with RNA. The $16 \mathrm{~S}$ rRNA gene was amplified by PCR by using two universal primers as described previously (Yoon et al., 1998). Sequencing of the amplified $16 \mathrm{~S}$ rRNA gene and phylogenetic analysis were performed as described by Yoon $e t$ al. (2003). The isomer type of the diamino acid in the cell-wall peptidoglycan was analysed by TLC according to Komagata \& Suzuki (1987). Isoprenoid quinones were extracted according to the method of Komagata \& Suzuki (1987) and were analysed by using reversed-phase HPLC and a YMC ODS-A $(250 \times 4.6 \mathrm{~mm})$ column. For cellular fatty acid analysis, cell mass of strain $\mathrm{ODN}^{\mathrm{T}}$ and the five reference strains was harvested from TSA plates after incubation for 3 days at $30{ }^{\circ} \mathrm{C}$. Fatty acids were extracted and fatty acid methyl esters were prepared according to the standard protocol of the MIDI/Hewlett Packard Microbial Identification System (Sasser, 1990). Polar lipids were extracted according to the procedures described by Minnikin et al. (1984) and were identified by twodimensional TLC followed by spraying with appropriate detection reagents (Minnikin et al., 1984; Komagata \& Suzuki, 1987). The presence of phosphatidylcholine was determined by spraying with Dragendorff's reagent (Sigma). The DNA G $+\mathrm{C}$ content was determined by the method of Tamaoka \& Komagata (1984) with a modifica- tion that DNA was hydrolysed and the resultant nucleotides were analysed by reversed-phase HPLC. DNA-DNA hybridization was performed fluorometrically by the method of Ezaki et al. (1989) by using photobiotin-labelled DNA probes and microdilution wells. Hybridization was performed with five replications for each sample. The highest and lowest values obtained in each sample were excluded and the mean of the remaining three values was quoted as the level of DNA-DNA relatedness.

The almost-complete 16S rRNA gene sequence of strain $\mathrm{ODN}^{\mathrm{T}}$ determined in this study comprised $1442 \mathrm{nt}$ (approximately $96 \%$ of the Escherichia coli $16 \mathrm{~S}$ rRNA gene sequence). Comparative $16 \mathrm{~S}$ rRNA gene sequence analysis showed that strain $\mathrm{ODN}^{\mathrm{T}}$ was phylogenetically most closely related to the genus Sphingomonas. In the neighbour-joining phylogenetic tree based on 16S rRNA gene sequences, strain $\mathrm{ODN}^{\mathrm{T}}$ fell within the cluster comprising Sphingomonas species, joining S. panni $\mathrm{C}_{5} 2^{\mathrm{T}}$ at a bootstrap resampling value of $99.9 \%$ (Fig. 1). The relationship between strain $\mathrm{ODN}^{\mathrm{T}}$ and $S$. panni $\mathrm{C}_{5} 2^{\mathrm{T}}$ was also maintained in the trees constructed via the maximumlikelihood and maximum-parsimony algorithms (Fig. 1). Strain $\mathrm{ODN}^{\mathrm{T}}$ exhibited $98.9 \% 16 \mathrm{~S}$ rRNA gene sequence similarity to $S$. panni $\mathrm{C} 52^{\mathrm{T}}$ and $93.8-98.0 \%$ similarity to the type strains of other recognized species of the genus Sphingomonas.

Strain $\mathrm{ODN}^{\mathrm{T}}$ contained ubiquinone-10 as the predominant isoprenoid quinone. The cellular fatty acid profile of strain $O D N 7^{\mathrm{T}}$ is given in Table 1, together with those of the type strains of the five Sphingomonas species also analysed

Table 1. Cellular fatty acid profiles of strain $\mathrm{ODN} 7^{\top}$ and the type strains of phylogenetically related Sphingomonas species

Strains: 1, ODN7 ${ }^{\mathrm{T}}$; 2, S. panni KACC $12169^{\mathrm{T}}$; 3, S. desiccabilis KACC $13216^{\mathrm{T}}$; 4, S. molluscorum JCM 14122 ${ }^{\mathrm{T}}$; 5, S. mucosissima DSM 17494 ${ }^{\mathrm{T}}$; 6, S. dokdonensis DS $-4^{\mathrm{T}}$. All data are from the present study. Values are percentages of the total fatty acids; components that represented $<0.5 \%$ in all strains were omitted. - , Not detected.

\begin{tabular}{|c|c|c|c|c|c|c|}
\hline Fatty acid & 1 & 2 & 3 & 4 & 5 & 6 \\
\hline \multicolumn{7}{|l|}{ Straight-chain } \\
\hline $\mathrm{C}_{14: 0}$ & 1.1 & 1.2 & 0.4 & 1.2 & 1.5 & 0.58 \\
\hline $\mathrm{C}_{15: 0}$ & 0.5 & - & 0.4 & 0.9 & 0.8 & 0.26 \\
\hline $\mathrm{C}_{16: 0}$ & 11.5 & 11.7 & 10.3 & 10.9 & 15.4 & 13.7 \\
\hline \multicolumn{7}{|l|}{ Unsaturated } \\
\hline $\mathrm{C}_{16: 1} \omega 5 c$ & 5.4 & 4.4 & 2.7 & 2.5 & 2.5 & 2.6 \\
\hline $\mathrm{C}_{16: 1} \omega 11 c$ & - & - & - & - & 1.2 & - \\
\hline $\mathrm{C}_{17: 1} \omega 6 c$ & 3.7 & 0.37 & 4.3 & 4.7 & 3.3 & 1.6 \\
\hline $\mathrm{C}_{17: 1} \omega 8 c$ & 0.5 & - & - & 0.6 & 0.3 & - \\
\hline $\mathrm{C}_{18: 1} \omega 5 c$ & 1.2 & 1.5 & 2.5 & 1.8 & 1.6 & 1.0 \\
\hline $\mathrm{C}_{18: 1} \omega 7 c$ & 53.9 & 54.5 & 58.9 & 53.6 & 43.7 & 47.2 \\
\hline \multicolumn{7}{|l|}{ Hydroxy } \\
\hline $\mathrm{C}_{14: 0} 2-\mathrm{OH}$ & 5.6 & 6.6 & 7.9 & 7.9 & 9.9 & 11.9 \\
\hline $\mathrm{C}_{15: 0} 2-\mathrm{OH}$ & 0.2 & - & 0.4 & 0.7 & 0.4 & - \\
\hline 11-Methyl $C_{18: 1} \omega 7 c$ & - & - & 3.9 & 4.9 & 5.7 & 5.0 \\
\hline Summed feature $3^{*}$ & 16.2 & 19.2 & 7.2 & 9.3 & 12.3 & 15.8 \\
\hline
\end{tabular}

*Summed features represent groups of two or three fatty acids that could not be separated by GLC with the MIDI system. Summed feature 3 comprised $\mathrm{C}_{16: 1} \omega 7 c$ and/or iso- $\mathrm{C}_{15: 0} 2-\mathrm{OH}$. 
in this study. Strain $\mathrm{ODN}^{\mathrm{T}}$ had large amounts of unsaturated, straight-chain and hydroxy fatty acids; the major components (>10\% of the total) were $\mathrm{C}_{18: 1} \omega 7 \mathrm{c}$, $\mathrm{C}_{16: 1} \omega 7 c$ and/or iso- $\mathrm{C}_{15: 0} 2-\mathrm{OH}$, and $\mathrm{C}_{16: 0}$. This fatty acid profile was similar to those of the five Sphingomonas species studied, although 11 -methyl $\mathrm{C}_{18: 1} \omega 7 c$ was not detected in strain $\mathrm{ODN}^{\mathrm{T}}$ or in S. panni KACC $12169^{\mathrm{T}}$ (Table 1). Major polar lipids found in strain $\mathrm{ODN} 7^{\mathrm{T}}$ were sphingoglycolipid, phosphatidylcholine, phosphatidylglycerol and phosphatidylethanolamine; small amounts of diphosphatidylglycerol, an unidentified phospholipid and an unidentified lipid were also detected. This polar lipid

Table 2. Differential phenotypic characteristics between strain ODN7 ${ }^{\top}$ and phylogenetically related Sphingomonas species

Taxa: 1, strain ODN7 ${ }^{\mathrm{T}}$; 2, S. panni; 3, S. desiccabilis; 4, S. molluscorum; 5, S. mucosissima; 6, S. dokdonensis. Data for reference species are from Busse et al. (2005), Reddy \& Garcia-Pichel (2007), Romanenko et al. (2007), Reddy \& Garcia-Pichel (2007) and Yoon et al. (2006) unless indicated otherwise. +, Positive reaction; -, negative reaction; w, weakly positive reaction. All are Gram-negative rods. All are positive for catalase, hydrolysis of aesculin and Tween 80 (data from the present study) and for the utilization of glucose, aesculin, cellobiose and trehalose. All are negative for utilization of erythritol, D-arabinose, ribose, L-xylose, adonitol, methyl $\beta$-D-xyloside, sorbose, dulcitol, inositol, mannitol, sorbitol, methyl $\alpha$-D-mannoside, inulin, glycogen, xylitol, D-lyxose, D-tagatose, D-arabitol, L-arabitol, 2-ketogluconate, caprate and phenylacetate.

\begin{tabular}{|c|c|c|c|c|c|c|}
\hline Characteristic & 1 & 2 & 3 & 4 & 5 & 6 \\
\hline Colony colour ${ }^{*}$ & $\mathrm{Y}$ & $\mathrm{Y}$ & $\mathrm{Y}$ & $\mathrm{Y}$ & LO & $\mathrm{Y}$ \\
\hline Motility & - & - & - & - & - & + \\
\hline Oxidase & + & - & + & + & + & + \\
\hline$\beta$-Galactosidase & - & + & + & + & - & - \\
\hline Nitrate reduction & - & $-\dagger$ & + & - & - & - \\
\hline 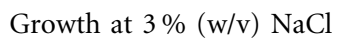 & - & $-\dagger$ & + & + & - & + \\
\hline \multicolumn{7}{|l|}{ Hydrolysis of: $\dagger$} \\
\hline Casein & - & - & - & - & - & + \\
\hline Gelatin & - & - & - & - & - & + \\
\hline Starch & - & + & + & + & + & + \\
\hline \multicolumn{7}{|l|}{ Utilization of: $\dagger$} \\
\hline $\mathrm{N}$-Acetylglucosamine & + & - & + & + & - & - \\
\hline Adipate & + & - & - & - & + & + \\
\hline Amygdalin & + & - & + & + & - & - \\
\hline L-Arabinose & + & w & + & + & - & - \\
\hline Arbutin & + & - & + & + & - & - \\
\hline Citrate & + & - & - & - & - & - \\
\hline Fructose & + & + & + & + & - & + \\
\hline D-Fucose & + & - & - & - & - & - \\
\hline L-Fucose & + & - & - & - & - & - \\
\hline Galactose & $\mathrm{w}$ & + & + & + & - & - \\
\hline Gentiobiose & + & + & + & + & - & - \\
\hline Gluconate & + & - & + & + & + & - \\
\hline Glycerol & - & - & - & - & + & + \\
\hline 5-Ketogluconate & + & - & - & - & - & - \\
\hline Lactose & + & + & + & + & - & - \\
\hline Malate & + & - & - & - & - & + \\
\hline Maltose & + & + & + & + & - & - \\
\hline Mannose & + & + & + & + & - & + \\
\hline Melezitose & + & - & + & + & - & - \\
\hline Melibiose & + & - & + & + & - & - \\
\hline Methyl $\alpha$-D-glucoside & + & - & + & + & - & - \\
\hline Raffinose & + & + & + & + & - & - \\
\hline Rhamnose & + & $\mathrm{w}$ & + & + & - & - \\
\hline Salicin & + & - & + & + & - & - \\
\hline Starch & + & + & - & - & - & - \\
\hline Sucrose & + & + & + & + & - & - \\
\hline Turanose & + & - & + & + & - & - \\
\hline D-Xylose & + & w & + & + & - & - \\
\hline
\end{tabular}

${ }^{\star}$ Data from the present study; all were grown at $30^{\circ} \mathrm{C}$ on TSA; Y, yellow; LO, light orange.

$\dagger$ Data from the present study. 
profile was similar to that of S. panni (Busse et al., 2005), the closest phylogenetic neighbour to strain $\mathrm{ODN}^{\mathrm{T}}$. The DNA G $+\mathrm{C}$ content of strain $\mathrm{ODN}^{\mathrm{T}}$ was $67.2 \mathrm{~mol} \%$. The results obtained from chemotaxonomic analyses, showing the characteristic properties shared by species of the genus Sphingomonas, were in agreement with the results of phylogenetic analysis, i.e. that strain $\mathrm{ODN}^{\mathrm{T}}$ may be a member of the genus Sphingomonas.

Strain ODN7 ${ }^{\mathrm{T}}$ exhibited levels of DNA-DNA relatedness of $15-32 \%$ to the type strains of the five phylogenetically related Sphingomonas species studied herein, namely $S$. panni (32\%), S. desiccabilis (23\%), S. molluscorum (28\%), S. mucosissima $(25 \%)$ and S. dokdonensis (15\%). Strain $\mathrm{ODN7}^{\mathrm{T}}$ was distinguishable from $S$. panni and other phylogenetically related Sphingomonas species based on differences in several phenotypic characteristics (Table 2). The phylogenetic and genetic distinctiveness and differential phenotypic properties of strain $\mathrm{ODN} 7^{\mathrm{T}}$ are sufficient to categorize it as a member of a species that is distinct from recognized Sphingomonas species (Wayne et al., 1987; Stackebrandt \& Goebel, 1994). Therefore, on the basis of the data presented, strain $\mathrm{ODN}^{\mathrm{T}}$ is considered to represent a novel species of the genus Sphingomonas, for which the name Sphingomonas hankookensis sp. nov. is proposed.

\section{Description of Sphingomonas hankookensis sp. nov.}

Sphingomonas hankookensis (han.kook.en'sis. N.L. fem. adj. hankookensis of Hankook, the Korean name for South Korea from where the type strain was isolated).

Cells are Gram-negative, non-motile rods $(0.3-0.6 \times 0.9-$ $2.8 \mu \mathrm{m})$. Colonies on TSA are circular, convex, smooth, yellow and $0.8-1.0 \mathrm{~mm}$ in diameter after incubation for 3 days at $30{ }^{\circ} \mathrm{C}$. Growth occurs at 4 and $37{ }^{\circ} \mathrm{C}$, but not at $40{ }^{\circ} \mathrm{C}$. Optimal pH for growth is around 7.0. Growth occurs at $\mathrm{pH} 5.0$ and 10.0 , but not at $\mathrm{pH} 4.5$ or 10.5 . Growth occurs in the presence of $0-1 \%(\mathrm{w} / \mathrm{v}) \mathrm{NaCl}$ (optimum $0-0.5 \%, \mathrm{w} / \mathrm{v}$ ). Negative for arginine dihydrolase, lysine decarboxylase, ornithine decarboxylase and tryptophan deaminase. $\mathrm{H}_{2} \mathrm{~S}$ and indole are not produced. Tweens 20, 40 and 60 are hydrolysed, but xanthine, hypoxanthine and tyrosine are not. Susceptible to chloramphenicol, gentamicin, neomycin, novobiocin, oleandomycin and tetracycline and weakly susceptible to kanamycin and polymyxin B. Resistant to ampicillin, carbenicillin, cephalothin, lincomycin, penicillin $G$ and streptomycin. The predominant ubiquinone is $\mathrm{Q}-10$. The major fatty acids $\left(>10 \%\right.$ of the total) are $\mathrm{C}_{18: 1} \omega 7 \mathrm{c}$, $\mathrm{C}_{16: 1} \omega 7 c$ and/or iso- $\mathrm{C}_{15: 0} \quad 2-\mathrm{OH}$, and $\mathrm{C}_{16: 0}$. Other phenotypic characteristics are given in Table 2.

The type strain, $\mathrm{ODN}^{\mathrm{T}} \quad\left(=\mathrm{KCTC} \quad 22579^{\mathrm{T}}=\mathrm{CCUG}\right.$ $57509^{\mathrm{T}}$ ), was isolated from a wastewater treatment plant in Taejon, Korea. The DNA G $+\mathrm{C}$ content of the type strain is $67.2 \mathrm{~mol} \%$ (determined by HPLC).

\section{Acknowledgements}

This study was supported by a grant from the Korea Healthcare Technology R\&D Project from the Ministry for Health, Welfare \& Family Affairs, Republic of Korea (Project No. A062622). We are grateful to the KACC for kindly providing the type strains of $S$. panni and $S$. desiccabilis.

\section{References}

Anzai, Y., Kim, H., Park, J.-Y., Wakabayashi, H. \& Oyaizu, H. (2000). Phylogenetic affiliation of the pseudomonads based on 16S rRNA sequence. Int J Syst Evol Microbiol 50, 1563-1589.

Busse, H.-J., Hauser, E. \& Kämpfer, P. (2005). Description of two novel species, Sphingomonas abaci sp. nov. and Sphingomonas panni sp. nov. Int J Syst Evol Microbiol 55, 2565-2569.

Cowan, S. T. \& Steel, K. J. (1965). Manual for the Identification of Medical Bacteria. London: Cambridge University Press.

Ezaki, T., Hashimoto, Y. \& Yabuuchi, E. (1989). Fluorometric deoxyribonucleic acid-deoxyribonucleic acid hybridization in microdilution wells as an alternative to membrane filter hybridization in which radioisotopes are used to determine genetic relatedness among bacterial strains. Int J Syst Bacteriol 39, 224-229.

Huang, H.-D., Wang, W., Ma, T., Li, G.-O., Liang, F.-L. \& Liu, R.-L. (2009). Sphingomonas sanxanigenens sp. nov., isolated from soil. Int $J$ Syst Evol Microbiol 59, 719-723.

Komagata, K. \& Suzuki, K. (1987). Lipid and cell-wall analysis in bacterial systematics. Methods Microbiol 19, 161-207.

Lányí, B. (1987). Classical and rapid identification methods for medically important bacteria. Methods Microbiol 19, 1-67.

Lee, K.-B., Liu, C.-T., Anzai, Y., Kim, H., Aono, T. \& Oyaizu, H. (2005). The hierarchical system of the 'Alphaproteobacteria': description of Hyphomonadaceae fam. nov., Xanthobacteraceae fam. nov. and Erythrobacteraceae fam. nov. Int J Syst Evol Microbiol 55, 1907-1919.

Minnikin, D. E., O’Donnell, A. G., Goodfellow, M., Alderson, G., Athalye, M., Schaal, A. \& Parlett, J. H. (1984). An integrated procedure for the extraction of bacterial isoprenoid quinones and polar lipids. J Microbiol Methods 2, 233-241.

Reddy, G. S. N. \& Garcia-Pichel, F. (2007). Sphingomonas mucosissima sp. nov. and Sphingomonas desiccabilis sp. nov., from biological soil crusts in the Colorado Plateau, USA. Int J Syst Evol Microbiol 57, 1028-1034.

Romanenko, L. A., Uchino, M., Frolova, G. M., Tanaka, N., Kalinovskaya, N. I., Latyshev, N. \& Mikhailov, V. V. (2007). Sphingomonas molluscorum sp. nov., a novel marine isolate with antimicrobial activity. Int J Syst Evol Microbiol 57, 358-363.

Romanenko, L. A., Tanaka, N., Frolova, G. M. \& Mikhailov, V. V. (2009). Sphingomonas japonica sp. nov., isolated from marine crustacean Paralithodes camtschatica from the Sea of Japan. Int J Syst Evol Microbiol 59, 1179-1182.

Sasser, M. (1990). Identification of bacteria by gas chromatography of cellular fatty acids, MIDI Technical Note 101. Newark, DE: MIDI Inc.

Stackebrandt, E. \& Goebel, B. M. (1994). Taxonomic note: a place for DNA-DNA reassociation and $16 \mathrm{~S}$ rRNA sequence analysis in the present species definition in bacteriology. Int J Syst Bacteriol 44, 846-849.

Tamaoka, J. \& Komagata, K. (1984). Determination of DNA base composition by reversed-phase high-performance liquid chromatography. FEMS Microbiol Lett 25, 125-128.

Wayne, L. G., Brenner, D. J., Colwell, R. R., Grimont, P. A. D., Kandler, O., Krichevsky, M. I., Moore, L. H., Moore, W. E. C., Murray, R. G. E. \& other authors (1987). International Committee on Systematic Bacteriology. 
Report of the ad hoc committee on reconciliation of approaches to bacterial systematics. Int J Syst Bacteriol 37, 463-464.

Yabuuchi, E., Yano, I., Oyaizu, H., Hashimoto, Y., Ezaki, T. \& Yamamoto, H. (1990). Proposals of Sphingomonas paucimobilis gen. nov. and comb. nov., Sphingomonas parapaucimobilis sp. nov., Sphingomonas yanoikuyae sp. nov., Sphingomonas adhaesiva sp. nov., Sphingomonas capsulata comb. nov., and two genospecies of the genus Sphingomonas. Microbiol Immunol 34, 99-119.

Yoon, J.-H., Kim, H., Kim, S.-B., Kim, H.-J., Kim, W. Y., Lee, S. T., Goodfellow, M. \& Park, Y.-H. (1996). Identification of Saccharomonospora strains by the use of genomic DNA fragments and rRNA gene probes. Int $J$ Syst Bacteriol 46, 502-505.
Yoon, J.-H., Lee, S. T. \& Park, Y.-H. (1998). Inter- and intraspecific phylogenetic analysis of the genus Nocardioides and related taxa based on 16S rRNA gene sequences. Int J Syst Bacteriol 48, 187-194.

Yoon, J.-H., Kang, K. H. \& Park, Y.-H. (2003). Psychrobacter jeotgali sp. nov., isolated from jeotgal, a traditional Korean fermented seafood. Int J Syst Evol Microbiol 53, 449-454.

Yoon, J.-H., Lee, M.-H., Kang, S.-J., Lee, S.-Y. \& Oh, T.-K. (2006). Sphingomonas dokdonensis sp. nov., isolated from soil. Int J Syst Evol Microbiol 56, 2165-2169.

Yoon, J.-H., Kang, S. J., Lee, S. Y. \& Oh, T. K. (2008). Sphingomonas insulae sp. nov., isolated from soil. Int J Syst Evol Microbiol 58, 231-236. 